\title{
Youth Subjectivities and Associational Life in Bamenda, Cameroon
}

\author{
Jude Fokwang*
}

\section{Introduction}

How do young people at the margins of national citizenship make sense of their lives in local society? What mechanisms do they employ to negotiate transition to full adult status in contexts where national institutional support for them has become tenuous or disappeared completely? How do we analyse and account for the ways in which younger generations of Africans, experiencing blocked mobility, deal with their predicament on account of postcolonial elites' continuous cling to power and resources? How, and in what contexts, are social categories (such as youth or adult) constructed, negotiated and experienced? These questions inevitably demand a critical discussion of the meanings of youth (understood in this study as a position of structural dependency), social adulthood, citizenship and social participation. This study answers the above questions by focusing on the subjectivities and activities of three associations of young men and women in Bamenda, Cameroon's leading Anglophone city. The associations include the Chosen Sisters, the United Sisters and the Ntambag Brothers Association (NBA).

Being an ethnographic study, context is essential for its appreciation. The study is set against a background of what is known popularly in Cameroon as la crise - crisis that conjures simply more than the spectres of economic and political uncertainty; indeed, understood by most as a deep moral crisis. Against this background, this study analyses the ways in which young Cameroonians create meaningful lives in local society. Clearly, youths embody the sharpening contradictions of the late capitalist era (cf. Comaroff and Comaroff 2005:23) and tend to be 'positioned at the leading edge of many aspects of contemporary social change, and experience acutely the risks and opportunities that new social conditions entail' (Hall, Coffey and Williamson 1999:501).

* Department of Social Anthropology, University of Cape Town.

Email: jude.fokwang@uct.ac.za. 
Faced with massive unemployment, many young Cameroonians feel their youth is protracted and accession to social adulthood delayed. This is specifically true for many young people in their 20s and 30s who remain jobless, unmarried and uncertain of their future, but are continuously reminded by the leadership to 'wait for their turn'. The protraction of young people's youth, or what James Côté (2000) has termed 'arrested adulthood', seems to be the defining preoccupation for many young people who, without succumbing to despair, continue to explore mechanisms of making ends meet while aspiring to middle-class status.

The study focuses on young people's associations which, I argue, can be understood as critical sites for the production and experience of a diverse range of subjectivities. By subjectivity, I refer to social actors' thoughts, sentiments, and embodied sensibilities, and especially their senses of self and self-world relations (Holland and Leander 2004:127). Subjectivity involves making choices about one's identities as well as resisting those identities that are imposed by others or outsiders (Brettell and Sargent 2006:4). In this sense, I argue that young people occupy multiple subject positions - some of which they define for themselves and others which are defined for them. Building on this claim, I argue that, for many young people in Bamenda, the processes of positioning and the production of personhood are largely experienced through involvement in associational life.

The study analyses the ways in which young people in Cameroon negotiate their youth against the predicament of potent forces (both global and national) that structure their marginalisation and undermine their aspirations for meaningful citizenship and social adult status. Central to my argument is the claim that, through associations, young people position themselves and claim adult status by participating as part of a collective in a range of social and moral projects - most of which draw on and celebrate customary markers of social adult status. Importantly, involvement in associational life also reveals other processes at play, such as the collective basis of performance, the drama of social and moral control, as well as signals of young people's aspirations to middle class status.

Critical to my analysis is the transition paradigm which, according to Ken Roberts, involves among other things, 'charting the routes via which young people from different ports of departure reach different adult destinations'(Roberts 2007:264). In this sense, I show that transition embodies process, difference and particularities rather than linear development (Soares 2000:209). I also draw on the concepts of personhood and subjectivitity to explain the ways in which social actors position themselves and are positioned in varying social contexts and hierarchies. In this vein, I attempt to make 
connections between the categories of gender, moral practice, personhood and citizenship.

\section{Gendered Identities}

How is gender a significant organisational principle among young people in Bamenda? I show that, while young women seek to reconfigure gender relations through specific kinds of activities and positionings, members of the NBA (whose membership is exclusively male) use their association to undermine female ascendancy and to assert the idea of male superiority, thereby resisting the possibility of a redefined gender order. These processes and the various constestations and identities generated thereof signal the view that there is more to associational life than the simple quest for social visilibity and claims to adult status.

The gendering of associational life in Bamenda is far from new but the reincarnation of old patterns in the face of changing contexts. The gendered nature of associational life among young people's associations in Bamenda points to the desire of social actors to position themselves differently and to carve out new biographic trajectories. In this study, I show that young urban women in Bamenda tend to opt for exclusively female associations. This is partly because it provides them broader scope to set their own agenda and partly as a response to national and international initiatives that assert women's issues, evidenced by the growing popularity of the International Women's Day (celebrated every 8 March).

Young men in the NBA on their part, seek to position themselves as superior. By dint of the kinds of activities undertaken by the NBA, members see themselves as occupying a superior moral high ground than their female counterparts leading to the emergence of certain masculinities, some of which are carefully staged in order to represent themselves as the leading youth association in the community and in other respects in opposition to feminine identities. The NBA for instance, consisting at the time of my fieldwork of predominantly unemployed young men, tended to construct and display signs of what Richard Waller (2006) has termed productive masculinity, which provided them with a sense of credibility and respectability in the neighbourhood. Productive masculinity is often associated with the world of work and responsible citizenship. It is the kind of masculinity predicated on a man's ability to work, provide for his family and ensure the general welfare of his family and kin-network or community. Unlike most members in the Chosen and United Sisters, who tended to be self-employed in the informal economy, most young men in the NBA often identified themselves as 'applicants' - meaning unemployed. As applicants, they could not easily assume to be 'productive' young men unless they redefined their 
understanding of what it meant to be 'productive' by including their participation in the social projects carried out by the NBA. Thus, many came to see these projects as productive and worthy causes, pursued on behalf of the community and aimed at the ultimate development of the neighbourhood. In this sense, they represented themselves as providers for the community and therefore productive.

\section{Morality and Moral Practice}

Another concern in this study is the question of moral practice, which remains the substance of much anthropological debate. This is because morality is often tied to questions of power and control. While some anthropologists emphasise an Aristotelian perspective of morality, expressed simply as the striving for human good (Lambek 2000:313), others maintain that like culture, it is a set of shared values that underlie certain practices (Zigon 2007:131). However, in this study I am interested in what may be termed the production of local moralities, that is, a set of practices defined and employed by local actors as constituting 'morality'. These practices are largely informed by Christian ethos and local customs.

One of the defining activities of youth associations in Old Town includes the pursuit of moral regeneration or in their own words, the fight against social ills. Social actors employ the term 'moral' in reference to a range of practices, beliefs and rules that are critical for the pursuit of human good. For example, all three associations involved in this study frequently justified their fight against social ills as essential to their raison d'être. Each association retained a series of rules or moral codes expected to be followed by members if they desired to remain in good standing in the association. Transgressions, such as sexual promiscuity or abortion, were seen not only as bringing dishonour to the association, but also undermined the broader agenda of pursuing moral regeneration.

\section{Citizenship}

This study also raises issues that relate to current debates on citizenship. Citizenship is often understood as a social status that derives its legitimacy from the state. But how does one understand citizenship in a context where the postcolonial state is perceived to have failed, or is structured in a way that overtly marginalises and excludes some of its members? Critics have pointed out that the claims of democratic citizenship are not only false (cf. Werbner 1998) but also that the dominant framework for understanding citizenship remains 'bounded' or chained to the nation-state (cf. Nyamnjoh 2006) - a link that needs to be interrogated and deconstructed. 
In a context where national citizenship for many Cameroonian youths means little more than carrying a passport, alternative forms of social participation (as seen in associational life) empties national citizenship of its false claims and raises critical questions about the meanings of local participation, identities and subjectivities. Associations therefore provide scope for the construction and articulation of new identities, sociabilities and emergent forms of citizenship, which potentially deny the state its primary role in defining citizenship.

\section{Conclusion}

This study demonstrates on the one hand, the interplay of structural forces (both global and national) that position young people into categories of dependency, thereby protracting their youth and, on the other hand, how they negotiate social adult status through involvement in associational life. Clearly, the study reveals that young people occupy different subject positions, which lead to the experience of different subjectivities. However, through youth associations, individual peculiarities blend with collective claims for social visibility and moral legitimacy. The fact that young people negotiate and articulate new gendered identities while laying claim to social adult status does not negate or exclude the multiple contestations, moral economies and hierarchies generated thereof. If anything, we learn that social formations such as youth associations permit us to appreciate the vast array of processes, power relations, claims and moralities generated by social agents who occupy different subject positions, which in turn shape and are shaped by history and the promise of a better future.

\section{References}

Brettell, C. B. and Sargent, C. F., 2006, 'Migration, Identity, and Citizenship: Anthropological Perspectives', American Behavioral Scientist 50 (1):3-8.

Comaroff, J. and Comaroff, J. L., 2005, 'Reflections on Youth, From the Past to the Postcolony', Makers and Breakers: Children and Youth in Postcolonial Africa, edited by F. de Boeck and A. Honwana, London: James Currey.

Côté, James E., 2000, Arrested Adulthood: The Changing Nature of Identity and Maturity in the Late-Modern World, New York: New York University Press.

Hall, T., Coffey, A. and Williamson, H., 1999, 'Self, Space and Place: youth identities and citizenship', British Journal of Sociology of Education 20:501-513.

Holland, D. and Leander, K., 2004, 'Ethnographic Studies of Positioning and Subjectivity: An Introduction', Ethos 32 (2):127-139.

Lambek, M., 2000, 'The Anthropology of Religion and the Quarrel between Poetry and Philosophy', Current Anthropology 41 (3):309-320. 
Nyamnjoh, F. B., 2006, Insiders \& Outsiders: Citizenship and Xenophobia in Contemporary Southern Africa, London: Zed Books.

Roberts, K., 2007, 'Youth Transitions and Generations: A Response to Wyn and Woodman', Journal of Youth Studies 10 (2):263-269.

Soares, C., 2000, 'Aspects of Youth, transitions, and the end of certainties', International Social Science Journal 164:209-217.

Waller, R., 2006, 'Rebellious Youth in Colonial Africa', Journal of African History 47:77-92.

Werbner, P., 1998, 'Exoticising Citizenship: Anthropology and the new Citizenship Debate’, Canberra Anthropology 21:1-27.

Zigon, J., 2007, 'Moral breakdown and the ethical demand: A theoretical framework for an anthropology of moralities', Anthropological Theory 7 (2):131-150. 